\title{
Pathogenesis-Related Protein Expression in the Apoplast of Wheat Leaves Protected Against Leaf Rust Following Application of Plant Extracts
}

\author{
Rabia Naz, Asghari Bano, Neil L. Wilson, David Guest, and Thomas H. Roberts
}

First and second authors: Department of Plant Sciences, Quaid-i-Azam University, Islamabad, Pakistan; third author: Faculty of Agriculture and Environment, and fourth and fifth authors: Department of Plant and Food Sciences, Faculty of Agriculture and Environment, University of Sydney, NSW 2006 Australia.

Accepted for publication 18 February 2014.

\begin{abstract}
Naz, R., Bano, A., Wilson, N. L., Guest, D., and Roberts, T. H. 2014. Pathogenesis-related protein expression in the apoplast of wheat leaves protected against leaf rust following application of plant extracts. Phytopathology 104:933-944.

Leaf rust (Puccinia triticina) is a major disease of wheat. We tested aqueous leaf extracts of Jacaranda mimosifolia (Bignoniaceae), Thevetia peruviana (Apocynaceae), and Calotropis procera (Apocynaceae) for their ability to protect wheat from leaf rust. Extracts from all three species inhibited P. triticina urediniospore germination in vitro. Plants sprayed with extracts before inoculation developed significantly lower levels of disease incidence (number of plants infected) than unsprayed, inoculated

cyproconazole at $4 \mu \mathrm{g} / \mathrm{liter}$ ) reduced disease incidence significantly more effectively than sprays of fungicide at $0.1 \%$ alone. Extracts of $J$. mimosifolia were most active, either alone $(1.2 \%)$ or in lower doses $(0.6 \%)$ in combination with $0.05 \%$ Amistar Xtra. Leaf extracts combined with fungicide strongly stimulated defense-related gene expression and the subsequent accumulation of pathogenesis-related (PR) proteins in the apoplast of inoculated wheat leaves. The level of protection afforded was significantly correlated with the ability of extracts to increase PR protein expression. We conclude that pretreatment of wheat leaves with spray formulations containing previously untested plant leaf extracts enhances protection against leaf rust provided by fungicide sprays, offering an alternative disease management strategy.
\end{abstract} controls. Sprays combining $0.6 \%$ leaf extracts and $2 \mathrm{mM}$ salicylic acid with the fungicide Amistar Xtra at $0.05 \%$ (azoxystrobin at $10 \mu \mathrm{g} / \mathrm{liter}+$

The plant apoplast plays a critical role in the transport of water and nutrients (60) and interactions between plants and pathogens (17). One response of plants to attempted infection by pathogens is to accumulate apoplastic proteins, including pathogenesisrelated (PR) proteins $(10,15)$. There are 17 widely occurring classes of PR proteins in the plant kingdom: PR-1a, PR-2 ( $\beta-1,3-$ glucanases), PR-3 (chitinase), PR-4 (chitinase), PR-5 (thaumatinlike protein), PR-6 (proteinase inhibitors), PR-7 (proteinase), PR8-PR-11 (additional chitinases), as well as the more recently included PR-12 (defensins), PR-13 (thionin), PR-14 (nonspecific lipid transfer proteins), PR-15 (oxalate oxidase), PR-16 (oxalateoxidase-like protein), and PR-17 (unknown) (64). The expression of genes encoding PR proteins at both the mRNA and protein level has been detected in a variety of cereals (44). PR proteins have been recovered from the intercellular washing fluids (IWFs) of wheat infected with stem rust (also known as black rust) (Puccinia graminis) (24).

Recent research has aimed to discover natural plant products that are environmentally safe and easily biodegradable alternatives to synthetic fungicides $(3,46,63)$. Plant extracts containing antimicrobial and resistance-inducing activities that provide pro-

Corresponding author: T. H. Roberts; E-mail address: thomas.roberts@sydney.edu.au

* The $\boldsymbol{e}$-Xtra logo stands for "electronic extra" and indicates that the online version contains three supplementary tables and two supplementary figures. Figures 1 and 2 appear in color online.

http://dx.doi.org/10.1094/PHYTO-11-13-0317-R

(C) 2014 The American Phytopathological Society
Additional keywords: foliar spray, leaf rust.

tection against infections are considered a sustainable method for controlling plant diseases (52).

Leaf rust (also known as brown rust) is caused by $P$. triticina, an obligatory biotrophic parasite. It is a severe fungal disease of wheat causing yield losses over a large geographical area of the world (30). Our aim was to analyze the apoplastic expression of PR proteins in wheat leaves pretreated with specific plant formulations before inoculation with $P$. triticina. The effectiveness of such treatments was compared with the application of salicylic acid (SA), a key molecule in plant defense signaling, and to a commonly used Group CK fungicide, Amistar Xtra (Syngenta Crop Protection, Sydney, Australia), which, in concentrated form, contains the active ingredients azoxystrobin (200 g/liter) and cyproconazole ( $80 \mathrm{~g} /$ liter). The exogenous application of SA is known to induce systemic acquired resistance (SAR) against biotic stresses in plants $(16,37)$, which manifests as a long-lasting resistance to the same or even unrelated pathogens (18).

During the hypersensitive response (HR), in which plant cells surrounding the site of infection undergo programmed cell death (PCD), enhanced endogenous levels of SA, ethylene, and jasmonate, as well as reactive oxygen species (ROS), act as signals to alter expression of specific defense genes $(18,34)$. Signaling upregulates the expression of phenylalanine ammonia lyase (PAL, a key defense enzyme), leading to the synthesis of antimicrobial molecules (including phytoalexins and PR proteins) and strengthening of physical barriers to colonization at the infection site (65).

Fungicides and other biocides may adversely affect the phylloplane and rhizosphere microflora, with unintended consequences for crop health. The effectiveness of these chemicals is also vulnerable to the appearance and selection of insensitive pathogen 
strains, and mixtures of chemicals with different modes of action are often used to extend the life of valuable active ingredients (39). Plant extracts may complement the use of synthetic biocides through direct toxicity $(58,69)$. Concerning plant extracts most relevant to this study, Jacaranda mimosifolia (L.) (Bignoniaceae) exhibited the highest yield of extractable components in aqueous leaf extracts reported to have antimicrobial potential (57). Thevetia peruviana (Pers.) K. Schum. (Apocynaeceae), also known as yellow oleander, has been reported to inhibit the growth of several bacterial and fungal strains $(19,54)$. Leaf, root, and stem extracts of Calotropis procera (Ait.) (Asclepidaceae) have been reported to have antifungal potential (38). The latex of $C$. procera has antifungal potential against seedborne fungal pathogens associated with wheat (48).

Plant extracts are also known to protect plants against disease through their ability to elicit plant defenses both systematically and locally (66). The defense responses activated include an oxidative burst, cell death (23), changes in cell wall composition that can inhibit the penetration of pathogens, and synthesis of antimicrobial compounds such as phytoalexins (21). The induction of systemic resistance in plants involves the direct activation of defense-related genes, resulting in stronger elicitation of defense mechanisms following the pathogen infection (14).

Our overall objective was to determine the molecular responses of a leaf rust-susceptible cultivar of wheat (Triticum aestivum 'Kenya 1483') to foliar treatments with leaf extracts of J. mimosifolia, T. peruviana, and $C$. procera prior to inoculation with $P$. triticina. The specific experimental aims were to (i) determine the effect of the leaf extracts on P. triticina spore germination in vitro, (ii) describe and compare symptom development on inoculated leaves following the various spray treatments, (iii) quantify the effects of the spray treatments on the expression of defenserelated genes in inoculated wheat leaves, (iv) describe the proteome of the apoplast of inoculated leaves by one- and twodimensional electrophoresis (1-DE and 2-DE, respectively) and identify differentially expressed proteins by mass spectrometry (MS), and (v) quantify the enzyme activities of selected PR proteins (peroxidases, chitinases, $\beta$-1,3-glucanases, and PAL) in the apoplast of treated and inoculated wheat leaves.

\section{MATERIALS AND METHODS}

Host plants and pathogen material. Leaf rust-susceptible Kenya 1483 wheat and the pathogen $P$. triticina pathotype 531,4,(6),(7),10,11,12 (PBI accession number 010047) were obtained from the Plant Breeding Institute (PBI) Cereal Rust Collection, University of Sydney, Australia.

Plant extracts selected after screening for antifungal activity. Three plant species-J. mimosifolia D. Don (Bignoniaceae), T. peruviana (Pers.) K. Schum. (Apocynaceae), and C. procera (Aiton) R. Br. ex W. T. Aiton (Apocynaceae)-were selected on the basis of the in vitro antifungal activity of their leaf extracts against $P$. triticina.

Preparation of plant extracts. Plant leaves were washed thoroughly with distilled water. The shade-dried leaves of the selected species were finely ground using an electric grinder and stored in air-tight containers for further use. To prepare the finally selected concentration (1.2\%) after screening, the powdered plant material (12 g) was extracted for $24 \mathrm{~h}$ in 1 liter of autoclaved water and kept at room temperature $\left(28\right.$ to $\left.30^{\circ} \mathrm{C}\right)$. After $24 \mathrm{~h}$, the extracts were filtered through four layers of cheesecloth and used in experiments.

In vitro test for spore germination. Bacterial agar (15\%) solutions (Merck, Melbourne, Australia) containing extracts (1.2\%) of J. mimosifolia, T. peruviana, and C. procera were tested for their effect on $P$. triticina urediniospore germination. Petri dishes containing agar solution alone were used as a negative control. Freshly harvested spores of $P$. triticina $(2 \mathrm{mg} / \mathrm{ml})$ were dispersed onto petri dishes and incubated in the dark at $20^{\circ} \mathrm{C}$. After $3 \mathrm{~h}$ of spore dispersion, the germinated spores were counted and the percent germination calculated. A spore was considered germinated when the length of the germ tube was 1.5 times greater than that of the spore.

Preparation of formulations. Extract formulations were prepared by mixing the selected plant leaf extracts, fungicide (Amistar Xtra), SA, and 0.6\% (vol/vol) Tween-80 (emulsifier). All formulations were packaged in 1-liter plastic bottles and stored in the dark at room temperature before application. Formulations prepared and applied as foliar spray $48 \mathrm{~h}$ before pathogen inoculation are shown in Table 1.

Leaf rust inoculation. Formulations of the selected plant extracts (J. mimosifolia, T. peruviana, and C. procera), fungicide, and SA were tested against $P$. triticina on wheat leaves in pot experiments under greenhouse conditions. Wheat seed were planted in $18-\mathrm{cm}$-diameter pots arranged at random in triplicate. Wheat seedlings were inoculated 12 days later with urediniospores of $P$. triticina suspended in mineral oil $(1 \mathrm{mg} / \mathrm{ml}$, Shellsol $\mathrm{T}$; Shell Chemicals, London) (28). The urediniospore suspension of $P$. triticina was sprayed onto all seedlings in a pot (not onto individual seedlings or individual leaves) from a simple spray bottle until run-off. Inoculated plants were incubated at $100 \%$ relative humidity in the dark for $24 \mathrm{~h}$ at $20 \pm 2{ }^{\circ} \mathrm{C}$. The infected plants were then kept in the greenhouse at $25 \pm 2{ }^{\circ} \mathrm{C}$.

Assessment of disease severity. Disease responses in seedlings treated with the various plant extract formulations were scored using the 0 to 4 infection type (IT) scale (42). Observations of disease symptoms were recorded 10 days after rust inoculation. Disease incidence was calculated using the following formula (26): disease incidence $(\%)=$ (number of infected plants $\times$ 100)/total number of plants.

Sample collection. Plant leaf tissues were collected at 24-h intervals for six consecutive days. Whole plants were randomly

TABLE 1. Treatments, including formulations prepared and applied as foliar sprays $48 \mathrm{~h}$ before pathogen inoculation

\begin{tabular}{ll}
\hline Treatments & Symbols \\
\hline Uninfected control & $\mathrm{Control}$ \\
Infected control with Puccinia triticina & $\mathrm{Pt}$ \\
Amistar Xtra $(0.1 \%)+P$. triticina & $\mathrm{Amx}+\mathrm{Pt}$ \\
J. mimosifolia $(1.2 \%)+$ P. triticina & $\mathrm{Jm}+\mathrm{Pt}$ \\
T. peruviana $(1.2 \%)+$ P. triticina & $\mathrm{Tp}+\mathrm{Pt}$ \\
C. procera $(1.2 \%)+P$. triticina & $\mathrm{Cp}+\mathrm{Pt}$ \\
Salicylic acid $(4 \mathrm{mM})+P$. triticina & $\mathrm{SA}+\mathrm{Pt}$ \\
J. mimosifolia $(0.6 \%)+$ Amistar Xtra $(0.05 \%)+P$. triticina & $\mathrm{Jm}+\mathrm{Amx}+\mathrm{Pt}$ \\
T. peruviana $(0.6 \%)+$ Amistar Xtra $(0.05 \%)+P$. triticina & $\mathrm{Tp}+\mathrm{Amx}+\mathrm{Pt}$ \\
C. procera $(0.6 \%)+$ Amistar Xtra $(0.05 \%)+P$. triticina & $\mathrm{Cp}+\mathrm{Amx}+\mathrm{Pt}$ \\
Salicylic acid $(2 \mathrm{mM})+$ Amistar Xtra $(0.05 \%)+P$. triticina & $\mathrm{SA}+\mathrm{Amx}+\mathrm{Pt}$ \\
J. mimosifolia $(0.6 \%)+$ salicylic acid $(2 \mathrm{mM})+P$. triticina & $\mathrm{Jm}+\mathrm{SA}+\mathrm{Pt}$ \\
T. peruviana $(0.6 \%)+$ salicylic acid $(2 \mathrm{mM})+P$. triticina & $\mathrm{Tp}+\mathrm{SA}+\mathrm{Pt}$ \\
C. procera $(0.6 \%)+$ salicylic acid $(2 \mathrm{mM})+P$. triticina & $\mathrm{Cp}+\mathrm{SA}+\mathrm{Pt}$ \\
\hline
\end{tabular}


harvested from different pots at the respective sampling times (during the period 10:00 a.m. to 12:00 noon). Plants were collected from each replication and treatment and were used to study the expression of PR and defense-related genes by reversetranscription quantitative polymerase chain reaction (RT-qPCR), and for the extraction of IWF to determine changes in protein concentration, protein complement (1-DE and 2-DE), and activities of defense-related enzymes.

Infiltration of wheat leaves and extraction of IWF. IWF was collected from all the leaves of infested and treated plants according to a published method (56), with some modifications. Collected leaves were washed with distilled water and only the upper $8 \mathrm{~cm}$ of each leaf was used. IWF was collected twice from the same leaves by centrifugation after vacuum infiltration with chilled infiltration buffer containing $50 \mathrm{mM}$ phenylmethanesulfonyl fluoride, Protease Inhibitor Cocktail Tablets, EDTA-Free (SigmaFAST), and $5 \mathrm{mM} \beta$-mercaptoethanol in a vacuum desiccator. A vacuum was applied for 8 min using a vacuum pump to remove the air from the apoplastic spaces during evacuation. A gradual release of the vacuum over a period of $20 \mathrm{~s}$ allowed the apoplastic spaces to be filled with infiltration buffer. Leaf segments were arranged in bundles in a nylon filter mesh. The leaf bundles were placed in a $20-\mathrm{ml}$ syringe in a $50-\mathrm{ml}$ Falcon tube and centrifuged at $3,000 \times g$ for $30 \mathrm{~min}$ at $4^{\circ} \mathrm{C}$. The extracted IWF was recentrifuged at $13,000 \mathrm{rpm}$ for $5 \mathrm{~min}$ in a microcentrifuge and stored at $-80^{\circ} \mathrm{C}$.

Estimation of contamination of IWF by intracellular proteins. The level of contamination of IWF by intracellular proteins was evaluated by determining the activity of the intracellular enzyme, malate dehydrogenase, in the IWF as compared with that in whole-leaf extract, according to a published method (22) as later modified (25). The whole-leaf extract was prepared using the trichloroacetic acid (TCA)/acetone method (55). The reaction was initiated by addition of aliquots of sample (IWF or total leaf extract) to a reaction mixture containing $0.17 \mathrm{mM}$ oxalacetic acid and $0.094 \mathrm{mM} \beta-\mathrm{NADH}$ (disodium salt) in $0.1 \mathrm{M}$ phosphate buffer, $\mathrm{pH}$ 7.5. The reaction was followed by the decrease in absorbance at $340 \mathrm{~nm}$ for $60 \mathrm{~s}$, using the same reaction mixture without sample as a blank.

RNA extraction and RT-qPCR. RNA was extracted from leaves using the Isolate RNA Plant Kit (Bioline) according to the manufacturer's instructions and quantified in a NanoDrop-ND1000 spectrophotometer (Thermo Fisher Scientific Inc., Melbourne, Australia) at a 1:10 (vol/vol) dilution. Purified RNA was used as template to synthesize cDNA using the Tetro cDNA Synthesis Kit (Bioline, Sydney, Australia). The reaction mixture contained Ribosafe RNase inhibitor $(1 \mu \mathrm{l})$, dNTP mix $(1 \mu \mathrm{l})$, oligo $(\mathrm{dT})_{18}$ $(1 \mu \mathrm{l})$, Tetro reverse transcriptase $(1 \mu \mathrm{l}), 5 \times \mathrm{RT}$ buffer, and diethylpyrocarbonate (DEPC)-treated water (to $20 \mu \mathrm{l}$ ), and was incubated at $37^{\circ} \mathrm{C}$ for $40 \mathrm{~min}$ and stored at $-20^{\circ} \mathrm{C}$.

Nine genes involved in plant responses to infection (as well as Actin) were selected for RT-qPCR analysis (primer sequences in Supplementary Table 1). Real-time reactions were performed using the SensiFAST SYBR Bo-ROX Kit (BioLine). The reaction consisted of $2.0 \mu \mathrm{l}$ of cDNA (30 ng) and a solution containing $3.2 \mu \mathrm{l}$ of DEPC-treated water, $0.4 \mu \mathrm{l}$ of forward primer $(10 \mu \mathrm{M}), 0.4 \mu \mathrm{l}$ of reverse primer $(10 \mu \mathrm{M})$, and $5 \mu \mathrm{l}$ of $2 \times$ SensiFAST SYBR Bo-ROX mix. Reactions were performed in triplicate for each sample, including negative controls in which cDNA was substituted by the same volume of water. A Bio-Rad CX96 thermocycler was used with the following conditions: 1 cycle of $95^{\circ} \mathrm{C}$ for $2 \mathrm{~min}, 1$ cycle of $95^{\circ} \mathrm{C}$ for $5 \mathrm{~s}, 1$ cycle of $60^{\circ} \mathrm{C}$ for $25 \mathrm{~s}$, and 39 cycles of $95^{\circ} \mathrm{C}$ for $5 \mathrm{~s}$ and $60^{\circ} \mathrm{C}$ for $25 \mathrm{~s}$. RT-qPCR data were analyzed using Bio-Rad CFX Manager (3.0) software.

Estimation of protein concentration. Protein concentration in the IWF from each treatment was determined using the Bradford method (11) with bovine serum albumin (BSA) as standard.
Estimation of peroxidase activity. Peroxidase (POD) activity was determined according to a published method (9), with modifications. An aliquot $(30 \mu \mathrm{l})$ of IWF was incubated with $1.8 \mathrm{ml}$ of $25 \mathrm{mM}$ guaiacol (2-methoxyphenol) and $100 \mu \mathrm{l}$ of $2 \% \mathrm{H}_{2} \mathrm{O}_{2}$ at room temperature for $2 \mathrm{~min}$, and the absorbance was measured at $470 \mathrm{~nm}$. One unit of POD activity is defined as causing a change of 0.01 absorbance units at $470 \mathrm{~nm}$ after incubation for $1 \mathrm{~min}$.

Estimation of chitinase activity. Chitinase activity was determined by colorimetric assay using the purple dye-labeled biopolymeric substrate, CM chitin-RBV (Loewe Biochemical, Munich, Germany) (61). An aliquot (200 $\mu$ l) of CM-chitin-RBV $(2 \mathrm{mg} / \mathrm{ml})$ was mixed with $300 \mu \mathrm{l}$ of protein extract and $300 \mu \mathrm{l}$ of $10 \mathrm{mM}$ Tris- $\mathrm{HCl}, \mathrm{pH} 7.5$, containing $1 \%$ Triton X-100. The reaction mixture was incubated at $37^{\circ} \mathrm{C}$ for $3 \mathrm{~h}$ and the reaction was stopped by the addition of $200 \mu \mathrm{l}$ of $2 \mathrm{M} \mathrm{HCl}$. Samples were cooled on ice for $15 \mathrm{~min}$ and then centrifuged at $20,000 \times g$ for 10 min to pellet the nondegraded substrate. The absorbance of the supernatant at $550 \mathrm{~nm}$ was measured in a BioTek Synergy H1 hybrid plate reader. One unit of chitinase activity is defined as giving an increase of absorbance of 0.1 at $550 \mathrm{~nm}$ (33).

Estimation of $\boldsymbol{\beta}$-1,3-glucanase activity. Glucanase activity was assayed according to a published method (1), with modifications. An aliquot $(400 \mu \mathrm{l})$ of extract plus $100 \mu \mathrm{l}$ of laminarin (a linear polysaccharide with a $\beta(1 \rightarrow 3) / \beta(1 \rightarrow 6)$ ratio of $3: 1)$ (Sigma, Sydney, Australia) at $2 \mathrm{mg} / \mathrm{ml}$ was incubated at $37^{\circ} \mathrm{C}$ for $15 \mathrm{~min}$. An aliquot $(400 \mu \mathrm{l})$ of dinitrosalicylate was added to the reaction mixture and boiled for $5 \mathrm{~min}$. After cooling, absorbance of the solution was measured at $500 \mathrm{~nm}$ in a BioTek Synergy H1 hybrid plate reader. Glucanase activity was expressed as units per milligram of protein, where one unit is defined as the reducing sugar equivalent to 10 nmole of glucose produced per second under the assay conditions.

Estimation of PAL activity. PAL activity was measured according to a published method (8), with modifications. An aliquot $(200 \mu \mathrm{l})$ of the extract was incubated with $0.5 \mathrm{ml}$ of $0.02 \mathrm{M}$

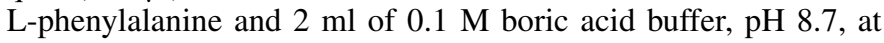
$30^{\circ} \mathrm{C}$ for $30 \mathrm{~min}$. The reaction was stopped by addition of $200 \mu \mathrm{l}$ of $6 \mathrm{M} \mathrm{HCl}$ and absorbance measured at $290 \mathrm{~nm}$ in a plate reader. The control mixture was stopped by adding $200 \mu \mathrm{l}$ of $6 \mathrm{M} \mathrm{HCl}$ immediately after mixing the extract with L-phenylalanine. One unit of PAL activity is defined as giving a change of 0.01 absorbance units at $290 \mathrm{~nm} / \mathrm{min}$.

Protein extraction for proteome analysis. Apoplastic proteins were precipitated using TCA/acetone following a published method (67), with modifications. Apoplastic soluble proteins (in $200 \mu \mathrm{l}$ ) were precipitated in 2 volumes of $10 \%$ ( $\mathrm{vol} / \mathrm{vol}$ ) TCA in acetone overnight at $-20^{\circ} \mathrm{C}$ and pelleted by centrifugation at $5,000 \times g$ for $10 \mathrm{~min}$. The pellet was resuspended in $0.07 \% \beta$ mercaptoethanol $(\mathrm{vol} / \mathrm{vol})$ in cold acetone. The samples were stored at $-20^{\circ} \mathrm{C}$ for $1 \mathrm{~h}$ and then centrifuged for $15 \mathrm{~min}$ at $10,000 \times g$ at $4^{\circ} \mathrm{C}$, with this step repeated. The supernatant was discarded and pellet dried under vacuum for $\approx 1 \mathrm{~h}$ and stored at $-80^{\circ} \mathrm{C}$.

Electrophoretic analyses. For 1-DE of proteins, NuPAGE LDS sample buffer (16 $\mu$ ) (Life Technologies, Melbourne, Australia) was added to $50 \mu \mathrm{l}$ of IWF containing $10 \mu \mathrm{g}$ of protein and heated at $70^{\circ} \mathrm{C}$ for $10 \mathrm{~min}$, according to the manufacturer's instructions. Proteins were resolved using NuPAGE 4 to $12 \%$ BisTris precast gels ( $\mathrm{pH} 7)$ under $200 \mathrm{~V}$ (constant) in an Invitrogen XCell SureLock Mini-Cell electrophoresis system (Life Technologies). Bands were visualized using a staining solution containing $0.1 \%$ (wt/vol) Coomassie R250, 40\% ethanol, and 10\% acetic acid and a destaining solution containing $10 \%$ ethanol and $7.5 \%$ acetic acid.

For 2-DE, pellets were dissolved in isoelectric focusing (IEF) rehydration buffer containing $5 \mathrm{M}$ urea, $2 \mathrm{M}$ thiourea, CHAPS ( $2 \% \mathrm{wt} / \mathrm{vol}$ ), sulfobetaine 3 to 10 (SB 3 to $10,2 \% \mathrm{wt} / \mathrm{vol})$, Tris (40 mM), Bio-Lyte 3/10 ampholyte (Bio-Rad catalog number $163-2094 ; 1 \% \mathrm{vol} / \mathrm{vol})$, Bromophenol blue $(0.05 \% \mathrm{wt} / \mathrm{vol})$, and 
dithiothreitol $(65 \mathrm{mM})$. Solubilized samples were centrifuged at $15,000 \times g$ for $10 \mathrm{~min}$ and an aliquot was used for protein quantification via the Bradford assay, with BSA as standard.

Samples containing $100 \mu \mathrm{g}$ of protein in rehydration buffer were applied on immobilized pH gradient (IPG) strips $(11 \mathrm{~cm}, \mathrm{pH}$ 3 to 10 nonlinear) by passive rehydration for $20 \mathrm{~h}$. The first dimension was run on a Bio-Rad Protean IEF cell system (BioRad) according to the manufacturer's instructions for the recommended voltage protocol (conditioning step: $200 \mathrm{~V}$ for $1 \mathrm{~h}$, voltage ramping to $10,000 \mathrm{~V}$ to give a total of $16 \mathrm{Vh}$ ). After reduction and alkylation were performed according to the manufacturer's instructions, the second dimension was run on a Criterion Bio-Rad system (Bio-Rad) using 4 to $12 \%$ Bis-Tris precast gels run in Bio-Rad MES running buffer at constant 180 V. Gels were stained first with Sypro Ruby $(100 \mathrm{ml})$ and imaged using a Typhoon FLA9000 fluorescence scanner, and then stained with Coomassie blue (G250) and imaged using a Bio-Rad GS-800 calibrated densitometer.

Spot detection was performed using PDQuest 2D analysis software (Bio-Rad) with default settings. All the IWF sample gels from the various treatments were compared with the inoculated control gel. After gel scanning, spots were visually selected and excised from Coomassie-stained gels for analysis.

Identification of proteins by MS. Protein bands and spots of interest were excised from Coomassie blue-stained 1-DE and 2DE gels. Tryptic digestion and electrospray ionization tandem MS (ESI-MS/MS) were performed as described (35). Briefly, gel plugs were destained two to four times for 10 min each in $60 \%$ (vol/vol) $20 \mathrm{mM}$ ammonium bicarbonate containing $40 \%$ (vol/vol) acetonitrile, rinsed twice in acetonitrile, dried with a vacuum centrifuge (Concentrator 5301; Eppendorf, Sydney, Australia), and rehydrated in $10 \mu \mathrm{l}$ of sequencing-grade porcine trypsin (Promega Corp., Sydney, Australia) at $12 \mathrm{ng} / \mu \mathrm{l}$ for $1 \mathrm{~h}$ at $4^{\circ} \mathrm{C}$. Excess trypsin was removed, $15 \mu \mathrm{l}$ of $20 \mathrm{mM}$ ammonium bicarbonate was added, and the samples were incubated at $37^{\circ} \mathrm{C}$ overnight. Peptides were concentrated and desalted using C18 micro-columns (Millipore, Melbourne, Australia) according to the manufacturer's protocol, eluted in $5 \mu \mathrm{l}$ of $70 \%$ acetonitrile and $0.1 \%$ formic acid into a low-bind 96-well plate (Eppendorf), and diluted with $45 \mu \mathrm{l}$ of $0.1 \%$ (vol/vol) formic acid. Peptides were desalted on a ZORBAX $300 \mathrm{SB}-\mathrm{C} 18$ trap $(5 \mu \mathrm{m}, 5$ by $0.3 \mathrm{~mm})$

TABLE 2. Germination percentage of urediniospores of Puccinia triticina incubated for $3 \mathrm{~h}$ on agar containing three different leaf extracts $(1.2 \%)$

\begin{tabular}{lc}
\hline Treatments & Germination $(\%)^{\mathrm{a}}$ \\
\hline Control $(\mathrm{C})$ & $95.0 \pm 3.0$ \\
Jacaranda mimosifolia $(\mathrm{Jm})$ & $3.0 \pm 0.5$ \\
Thevetia peruviana $(\mathrm{Tp})$ & $21.0 \pm 1.0$ \\
Calotropis procera $(\mathrm{Cp})$ & $45.0 \pm 2.0$ \\
\hline
\end{tabular}

a Data represent means \pm standard errors $(n=3)$.

TABLE 3. Phenotypic effects of plant extract formulations on wheat leaves after infection with Puccinia triticina

\begin{tabular}{lc}
\hline Treatments & Infection type \\
\hline $\mathrm{Pt}$ & 4 \\
$\mathrm{Amx}+\mathrm{Pt}$ & $;$ \\
$\mathrm{Jm}+\mathrm{Pt}$ & $2+$ \\
$\mathrm{Tp}+\mathrm{Pt}$ & $3+$ \\
$\mathrm{Cp}+\mathrm{Pt}$ & $3+$ \\
$\mathrm{SA}+\mathrm{Pt}$ & $3+$ \\
$\mathrm{Jm}+\mathrm{Amx}+\mathrm{Pt}$ & $0, ;$ \\
$\mathrm{Tp}+\mathrm{Amx}+\mathrm{Pt}$ & $0, ;$ \\
$\mathrm{Cp}+\mathrm{Amx}+\mathrm{Pt}$ & $0, ;$ \\
$\mathrm{SA}+\mathrm{Amx}+\mathrm{Pt}$ & 2 \\
$\mathrm{Jm}+\mathrm{SA}+\mathrm{Pt}$ & $2+$ \\
$\mathrm{Tp}+\mathrm{SA}+\mathrm{Pt}$ & $2+$ \\
$\mathrm{Cp}+\mathrm{SA}+\mathrm{Pt}$ & $3-$ \\
\hline
\end{tabular}

(Agilent Technologies, Melbourne, Australia) and separated using an in-house-prepared fritted nanocolumn packed with ReprosilPur C18 ( $3 \mu \mathrm{m}, 75 \mu \mathrm{m}$ by $150 \mathrm{~mm}$; Dr. Maish, GmbH, Ammerbuch, Germany) on an Agilent 1100 high-performance liquid chromatography system coupled to an AB Sciex Q-STAR Elite Qtime-of-flight mass spectrometer for analysis. Peptides were eluted using a gradient of 5 to $40 \%$ buffer B $(0.1 \%$ [vol $/ \mathrm{vol}]$ formic acid in acetonitrile) mixed with buffer A $(0.1 \%$ [vol/vol] formic acid) at a flow rate of $0.3 \mu \mathrm{l} / \mathrm{min}$. MS survey scans were performed over a range of 350 to $1,750 \mathrm{~m} / \mathrm{z}$ followed by three data-dependent MS/MS scans over a range of 65 to $2,000 \mathrm{~m} / \mathrm{z}$.

Bioinformatic analysis. Peak lists were generated using ProteinPilot Command Driver v.0.3 software (AB Sciex, Melbourne, Australia) and analyzed using MASCOT v.2.4 database

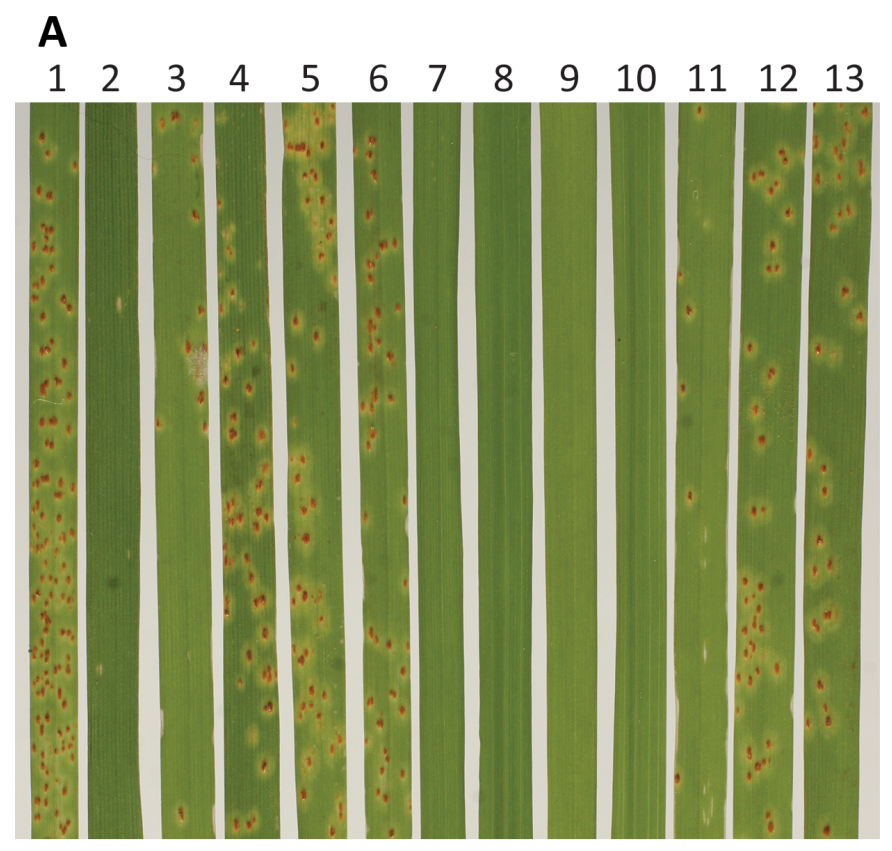

B

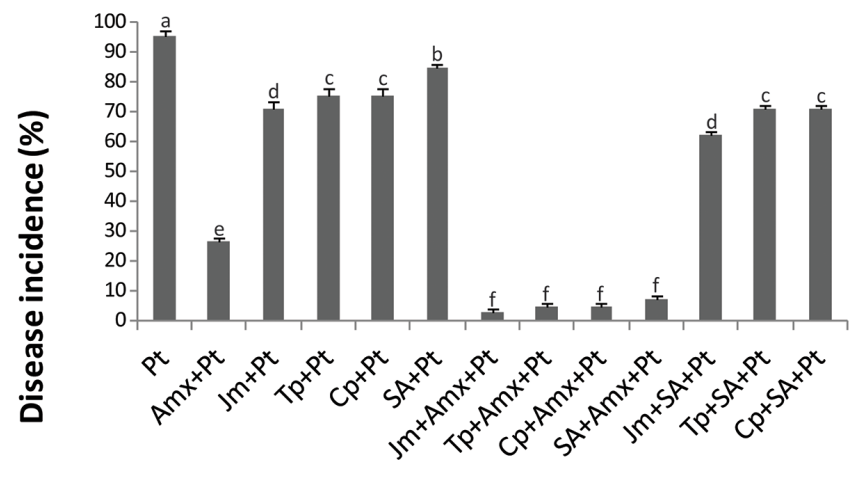

Formulations

Fig. 1. Representative effects of plant extract formulations (spray pretreatments) on disease incidence of wheat leaves inoculated with leaf rust (Puccinia triticina). A, Lane 1, inoculated control (P. triticina). Lane 2, fungicide (Amistar Xtra [Amx] [0.1\%]). Lane 3, Jacaranda mimosifolia (1.2\%). Lane 4, Thevetia peruviana (1.2\%). Lane 5, Calotropis procera $(1.2 \%)$. Lane 6, salicylic acid (SA) (4 mM). Lane 7, J. mimosifolia $(0.6 \%)+$ Amx $(0.05 \%)$. Lane 8, T. peruviana $(0.6 \%)+$ Amx $(0.05 \%)$. Lane 9, C. procera $(0.6 \%)+\operatorname{Amx}(0.05 \%)$. Lane 10 , SA $(2 \mathrm{mM})+\mathrm{Amx}(0.05 \%)$. Lane 11, J. mimosifolia $(0.6 \%)+\mathrm{SA}(2 \mathrm{mM})$. Lane 12, T. peruviana $(0.6 \%)+\mathrm{SA}$ $(2 \mathrm{mM})$. Lane $13, C$. procera $(0.6 \%)+\mathrm{SA}(2 \mathrm{mM})$. B, Data represent mean numbers of plants infected as percentage of total with standard errors $(n=3)$. Values with different letters are significantly different at $P \leq 0.05$ using an least significant difference test. Labeling is explained in Table 1. 
(Matrix Science, London) against the NCBInr (2013-03-03, 201303-26) database taxonomically restricted to Triticum aestivum proteins. Repeat searches were performed against all Viridiplantae sequences. One missed cleavage per peptide, a mass tolerance of $0.2 \mathrm{Da}$, variable modification by oxidation of methionine, and propionamide modification of cysteine were allowed in the MASCOT search. Significant $(P \leq 0.05)$ MASCOT scores, with two peptides matched for almost all proteins (one peptide for the remaining proteins), were considered a positive protein identification.

Statistical analysis. Data were expressed as mean \pm standard error $(n=3)$ for each sample. The values of some activities were subjected to analysis of variance using Statistix v.8.1. Comparison between mean values of treatments was made by least significant difference to test significant differences at $P \leq 0.05$ (20). Pearson's correlation coefficients were calculated by using Statistix v.8.1 to determine the relationship between expression of each PR gene and the reduction in disease incidence.

\section{RESULTS}

In vitro testing of plant extracts against spore germination. Extracts of J. mimosifolia, Thevetia peruviana, and C. procera inhibited $P$. triticina spore germination after $3 \mathrm{~h}$ by 97, 78, and $53 \%$, respectively (Table 2; Supplementary Figure 1).

Leaf rust IT. All spray formulations (Table 1) were evaluated against leaf rust for IT using a scale of 0 to $4+(42)$. The inocu- lated control developed IT 4+, while single applications of plant extracts (J. mimosifolia, T. peruviana, and C. procera) or combined formulations of plant extracts with SA gave IT values of 2 to $3+$ to $3-$ (Table 3 ). Fungicide application alone resulted in a low IT of ; while the half-dose formulations of plant extracts with fungicide gave IT 0 ;

Disease incidence. All treatments reduced disease incidence (percentage of the total number of plants developing symptoms of IT 2 or higher) compared with untreated, inoculated plants (Fig. 1). Fungicide reduced disease incidence by $72 \%$ compared with the infected control. Treatments with aqueous extracts of J. mimosifolia, $T$. peruviana, and $C$. procera combined with fungicide were the most effective, reducing $P$. triticina incidence by 98,95 , and $95 \%$, respectively, as compared with the untreated, inoculated control. The half-dose formulations of the three leaf extracts with SA gave 25, 23, and $23 \%$ reductions in disease incidence, respectively.

Differential expression of defense-related genes at the transcript level. Expression patterns of defense-related genes following plant extract treatments (with and without fungicide and SA) and inoculation with $P$. triticina were analyzed using RT-qPCR (Fig. 2; Supplementary Table 2). The induction patterns in wheat leaves were evaluated $24 \mathrm{~h}$ after inoculation. The housekeeping gene Actin was used as an RT-qPCR internal control. All the treatments resulted in substantial upregulation of the selected genes in response to leaf rust inoculation, which correlated significantly with the reduction in disease incidence (Supplementary Table 3).

\section{Chi-1 Chi-4 Glu-1 POD PR1.1 PR1.2 PR1.a PR-4 PR-5}

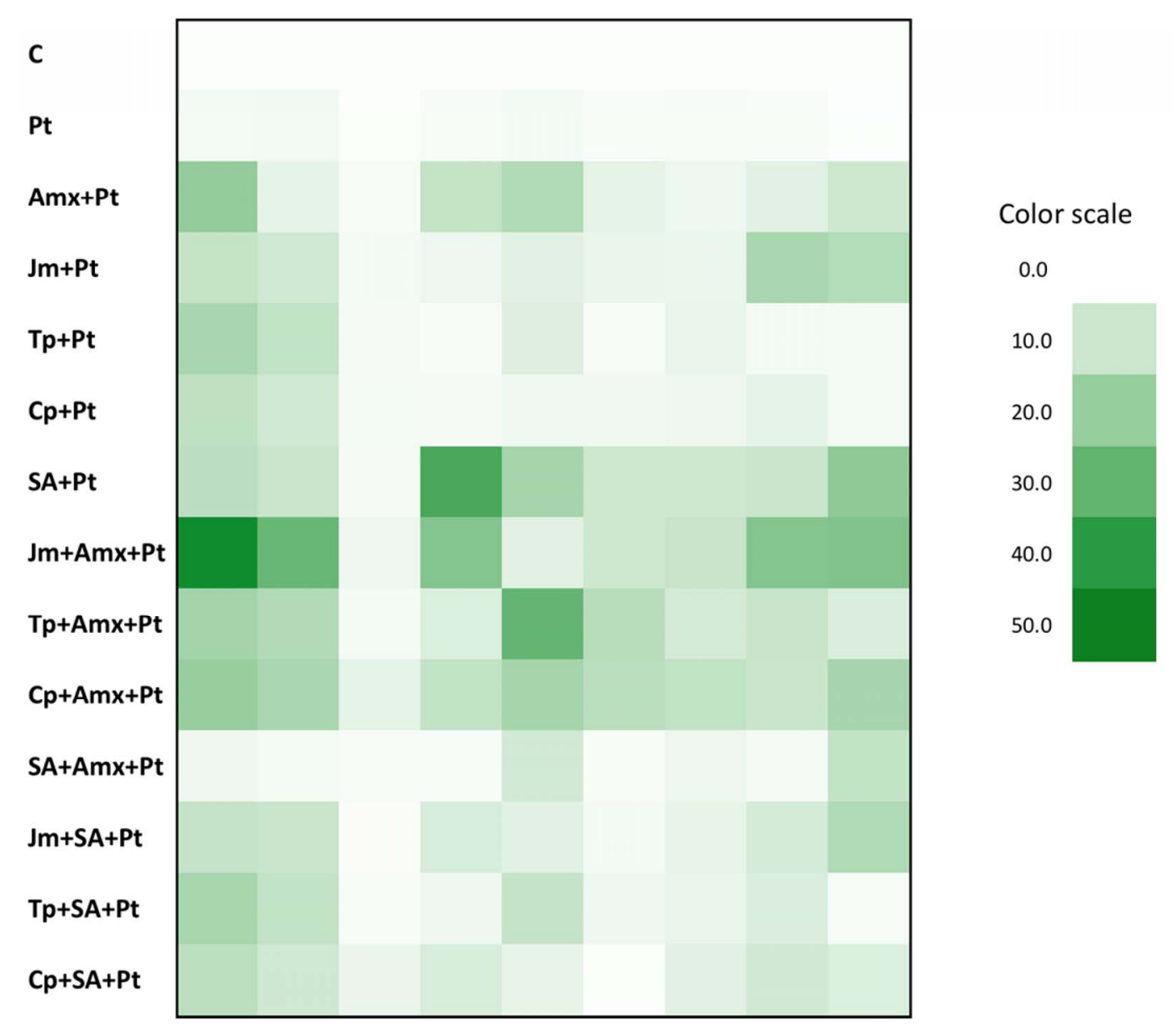

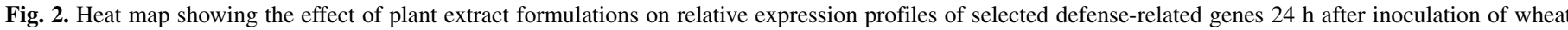

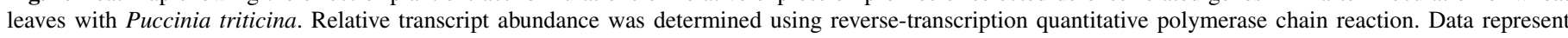
means $(n=3)$ with standard errors shown in Supplementary Table 2. Values given with color scale represent fold up-regulation. Labeling is explained in Table 1. 
Chitinase, $\boldsymbol{\beta}$-glucanases, and peroxidases. Two chitinase genes, Chil and Chi4, were upregulated $24 \mathrm{~h}$ after inoculation in plants treated with full- as well as half-dose formulations of the plant extracts. The J. mimosifolia extract combined with fungicide induced the greatest upregulation of Chil and Chi4 (by 43- and 26-fold, respectively) compared with the untreated inoculated control. All other treatments induced increases in the level of expression of Chil (10- to 20-fold) and Chi4 (2- to 16-fold) when compared with the untreated, inoculated control (Fig. 2).

All formulations induced expression of Glul (encoding an acidic $\beta$-1-3-glucanase) $24 \mathrm{~h}$ after inoculation by two- to fivefold compared with the infected control. $C$. procera extracts in combination with fungicide induced expression of Glul by fourfold when compared with the inoculated control. C. procera extract in combination with SA and $J$. mimosifolia combined with fungicide gave three- and twofold increases, respectively, in Glul expression compared with the inoculated control (Fig. 2).

All treatments increased the expression of $P O D$ genes from 2to 35 -fold $24 \mathrm{~h}$ after inoculation compared with the inoculated control (Fig. 2). The exogenous application of SA increased the expression of $P O D$ 33-fold compared with the inoculated control. The half-dose formulation of $J$. mimosifolia combined with fungicide resulted in a 22-fold increase in POD expression as compared with the untreated, inoculated control.

PR-1.1, PR-1.2, PR-1a, PR-4, and PR-5. Both PR-1.1 and PR-1.2 were upregulated in all the treatments, although the extent of this varied greatly (Fig. 2). The formulations of T. peruviana with fungicide, $C$. procera with fungicide, and exogenous application of SA induced expression of PR-1.1 $24 \mathrm{~h}$ after pathogen inoculation by 27-, 15-, and 14-fold, respectively, when compared with the inoculated control. Formulations with fungicide of T. peruviana, C. procera, and J. mimosifolia increased PR-1.2 expression 13-, 12-, and 8-fold, respectively, compared with the inoculated control.

A several-fold upregulation of PR-1a expression was observed across all treatments but the highest levels of induction were observed in plants treated with $C$. procera extract combined with fungicide (10-fold) and J. mimosifolia extract with fungicide (9fold), compared with the inoculated control (Fig. 2).

Upregulation of PR-4 and PR-5 expression was observed with all the plant extract formulations, ranging from 2- to 23-fold and 3 - to 24-fold, respectively, compared with the uninoculated and inoculated control (Fig. 2). The maximum upregulation was

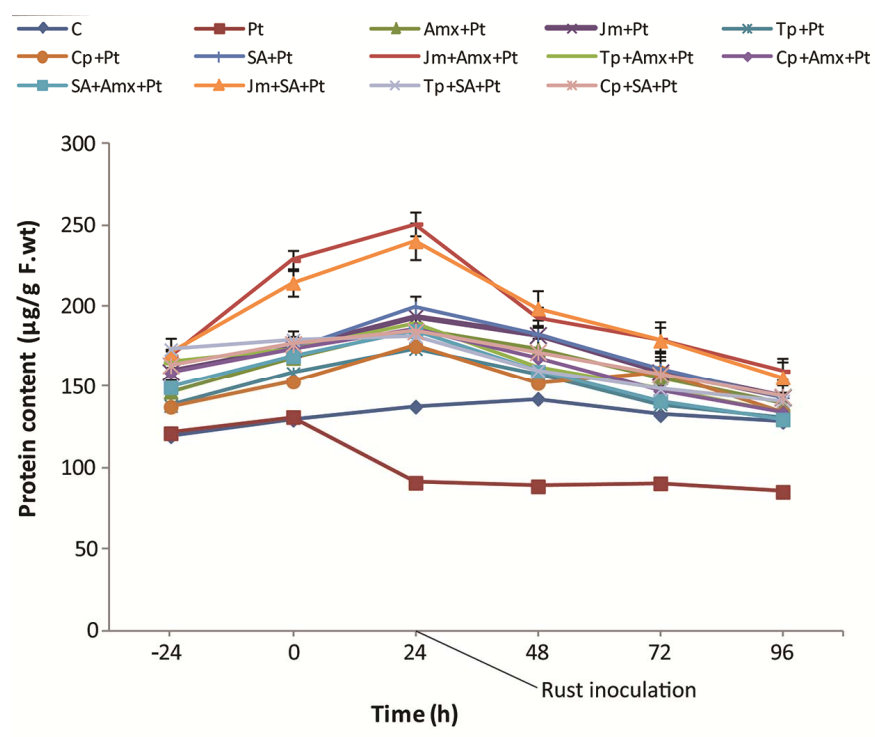

Fig. 3. Effect of various plant extract formulations on the protein content of wheat infected with leaf rust (Puccinia triticina). Data represent means with standard errors $(n=3)$. Labeling is explained in Table 1. observed following treatment with $J$. mimosifolia combined with fungicide, which gave an induced expression of 22- and 23-fold for PR-4 and PR-5, respectively, compared with the inoculated control.

Validation of apoplastic protein isolation and estimation of protein concentration. Levels of cytoplasmic contamination of the IWF samples were calculated from the percentage of malate dehydrogenase (MDH) activity in the IWF compared with that of whole-leaf extract (Supplementary Figure 2). IWF samples that showed MDH activity $>0.5 \%$ of the activity in whole-leaf extracts were discarded.

Protein concentrations were higher in the IWF from treated, inoculated plants when compared with untreated, inoculated plants (Fig. 3). Protein concentrations peaked $24 \mathrm{~h}$ after inoculation, followed by a decline from 48 to $96 \mathrm{~h}$. All the treatments gave a higher protein concentration compared with the inoculated control. Single applications of Amistar Xtra $(0.1 \%) ; J$. mimosifolia, T. peruviana, or C. procera extracts (1.2\%); or SA (4 mM) gave increases in protein content by $105,113,91,93$, and $119 \%$, respectively. Leaf extracts $(0.6 \%)$ of $J$. mimosifolia, $T$. peruviana, or $C$. procera combined with SA $(2 \mathrm{mM})$ resulted in increases in protein concentration of 164,100 , and $103 \%$, respectively, while the three half-dose plant extract formulations (0.6\%) with Amistar Xtra $(0.05 \%)$ gave even greater increases in protein concentration over the inoculated control plants $(176,108$, and $105 \%$, respectively). Treatment with extracts of J. mimosifolia, either alone or in combination with Amistar Xtra, consistently resulted in the highest wheat leaf IWF protein concentration.

1-DE. To identify proteins in the apoplast of wheat leaves treated with various formulations prior to pathogen inoculation, IWF samples were first analyzed using 1-DE (sodium dodecyl sulfate polyacrylamide gel electrophoresis). Coomassie staining of the 1-DE gel revealed protein bands with a molecular mass of 10 to $100 \mathrm{kDa}$. Bands representing proteins induced in response to plant treatments and pathogen inoculation were documented (Fig. 4).

2-DE. Because 1-DE indicated the presence of differentially expressed proteins, the IWF samples were additionally analyzed by 2-DE. The proteomic pattern of the IWF from untreated, inoculated control plants was compared with the pattern from plants treated with the full-dose formulations (1.2\%) of J. mimosi-

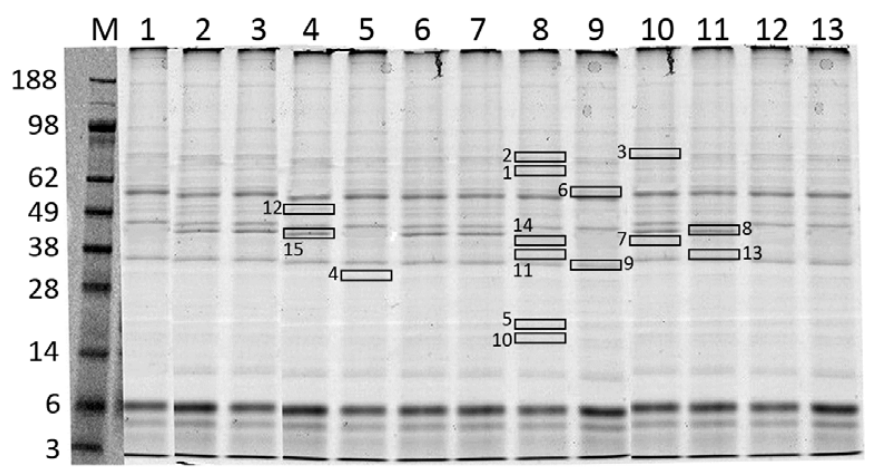

Fig. 4. One-dimensional electrophoresis of intercellular washing fluid proteins from wheat leaves pretreated with various plant extract formulations and inoculated with leaf rust (Puccinia triticina). $\mathrm{M}=$ molecular weight standards. Proteins were resolved using a 4 to $12 \%$ Bis-Tris gel stained with Coomassie R250. Protein bands bounded by rectangles in the various lanes were identified by electrospray ionization tandem mass spectrometry (Table 4). Lane 1, inoculated control ( $P$. triticina). Lane 2, fungicide (Amistar Xtra [Amx] [0.1\%]). Lane 3, salicylic acid (SA) (4 mM). Lane 4, Jacaranda mimosifolia (1.2\%). Lane 5, Thevetia peruviana (1.2\%). Lane 6, Calotropis procera $(1.2 \%)$. Lane 7, SA (2 mM) + Amx (0.05\%). Lane 8, J. mimosifolia $(0.6 \%)+$ Amx $(0.05 \%)$. Lane $9, T$. peruviana $(0.6 \%)+$ Amx $(0.05 \%)$. Lane 10, C. procera $(0.6 \%)+$ Amx $(0.05 \%)$. Lane 11, J. mimosifolia $(0.6 \%)+$ SA $(2 \mathrm{mM})$. Lane $12, T$. peruviana $(0.6 \%)+\mathrm{SA}(2 \mathrm{mM})$. Lane 13, C. procera $(0.6 \%)+\mathrm{SA}(2 \mathrm{mM})$. 
folia and C. procera and half-dose formulations of J. mimosifolia, T. peruviana, or C. procera and fungicide (Fig. 5).

The IWF proteins were found to have a pI range of 3 to 10 and mass range of 10 to $250 \mathrm{kDa}$. Clear differences were observed between the apoplastic proteins from control (Fig. 5A) and treated (Fig. 5B to F) plants. In total, 29 spots either absent from the control or more abundant following treatments were selected via staining with Sypru Ruby followed by Coomassie blue R250. Of the 10 spots selected from the J. mimosifolia-treated sample gel (Fig. 5B), spots 2 and 6 were absent in the IWF of untreated plants. Three to four spots were selected for identification on the basis of their increased abundance in IWF from plants treated with $C$. procera (Fig. 5C), J. mimosifolia in combination with fungicide (Fig. 5D), T. peruviana with fungicide (Fig. 5E), and $C$. procera with fungicide (Fig. 5F).

Protein identification by MS. To identify the IWF proteins, bands from the 1-DE gels (Fig. 4) and spots from the 2-DE gels (Fig. 5) were excised, digested with trypsin, and analyzed using
ESI-MS/MS (Tables 4 and 5). Most of the proteins were identified from several peptides. From 1-DE, proteins 4-hydroxyphenylpyruvate dioxygenase and $\beta$-1,3-glucanase were identified in response to the full-dose formulation of J. mimosifolia, whereas the half-dose formulation of $J$. mimosifolia with fungicide induced the highest number of proteins, including subtilisin protease, $\beta$-glucosidase, unknown protein 18 , pathogenesis-related protein 3-2 (chitinase and glucanases), and endochitinase, in response to leaf rust inoculation. Different classes of peroxidases were also induced following inoculation in response to half-dose formulations of fungicide with $T$. peruviana or $C$. procera extracts and J. mimosifolia with SA (Table 4).

The 2-DE gel representing leaf treatment with the full-dose formulation of $J$. mimosifolia revealed hypothetical protein VITISV_019908, subtilisin-like protease, $(1,3 ; 1,4) \beta$-glucanase, cyclophilin-like protein, an unknown type of protein, and $\mathrm{Cu} / \mathrm{Zn}$ superoxide dismutase as more abundant than in the control gel. The half-dose formulation of $J$. mimosifolia with fungicide
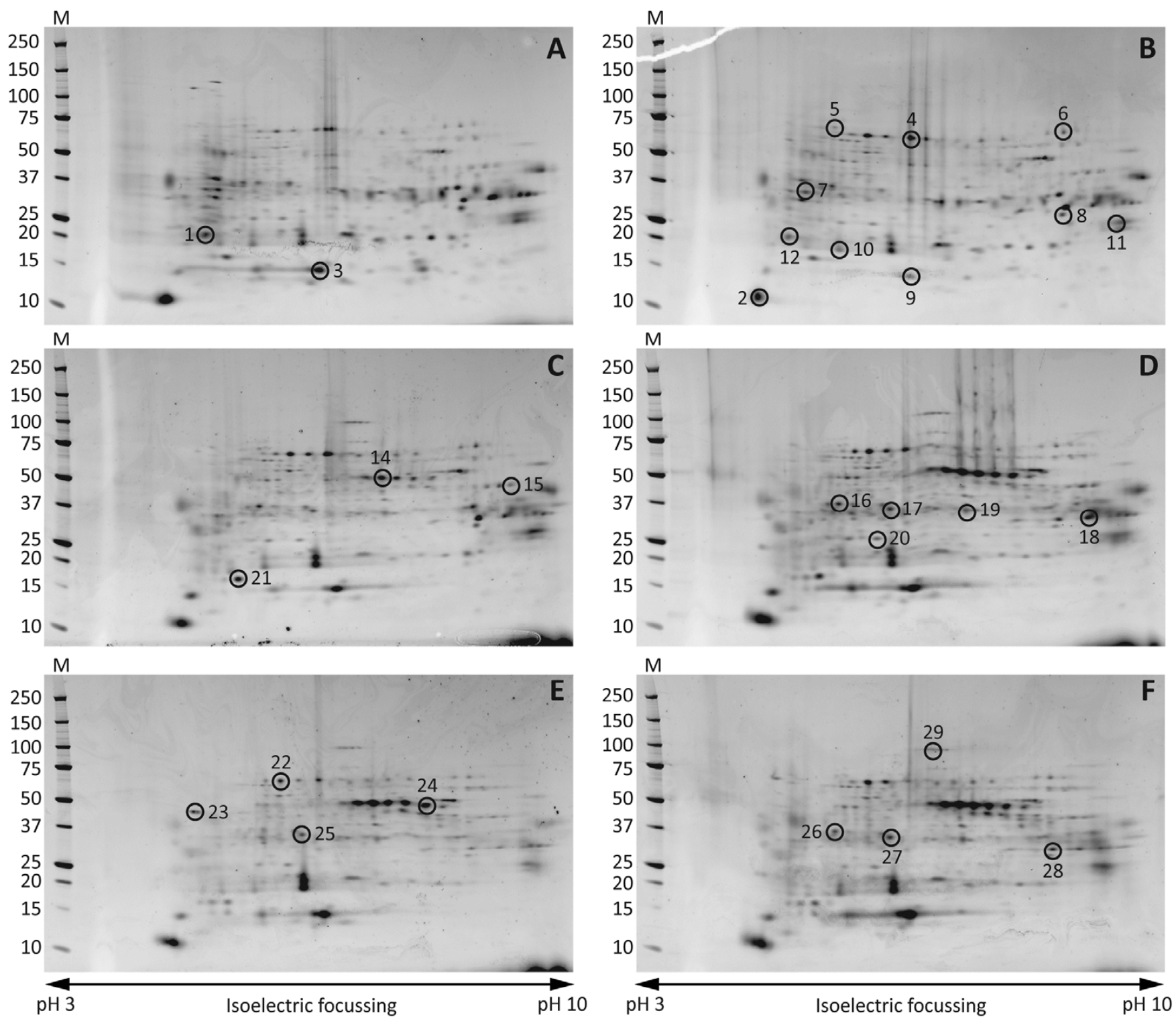

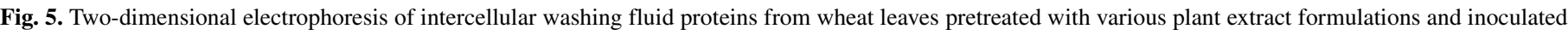

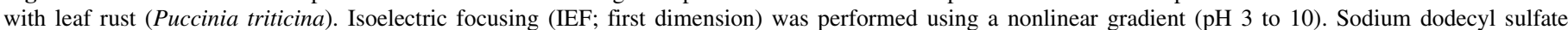

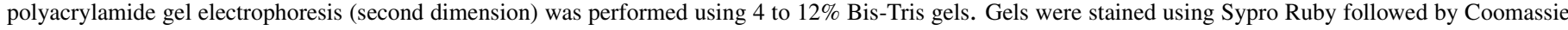

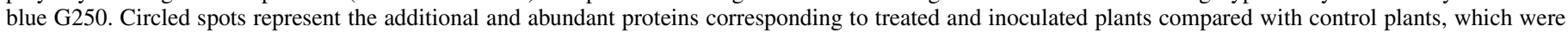

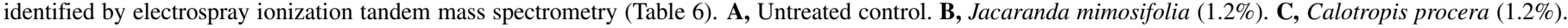

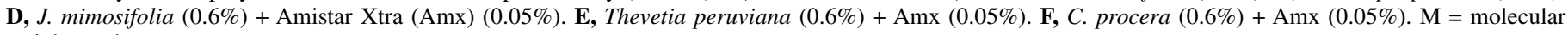
weight marker. 
induced TPA: hypothetical protein ZEAMMB73_571858, peroxidase 54 -like, $(1,3 ; 1,4)-\beta$-glucanase, and class III peroxidase (Table 5). Half-dose formulations of $T$. peruviana or $C$. procera with fungicide gave a number of hypothetical proteins, including $(1,3 ; 1,4)$ - $\beta$-glucanase and peroxidases. Almost all of the proteins identified in response to the various treatments after pathogen inoculation are PR proteins.

Effect of plant extract formulations on defense-related enzyme activities. Inoculation stimulated the activities of defenserelated enzymes in all treatments (Fig. 6).

Peroxidase activity. Following inoculation, peroxidase activity was higher in the formulation-treated plants than in untreated plants (Fig. 6A). Peroxidase activity peaked $24 \mathrm{~h}$ after inoculation, then declined from 48 to $96 \mathrm{~h}$. Inoculation of plants treated with Amistar Xtra; extracts of J. mimosifolia, T. peruviana, or $C$. procera; or SA alone induced peroxidase activity after 24 h by 78 , $72,46,47$, and $88 \%$, respectively. Half-dose formulations of aqueous leaf extracts of $J$. mimosifolia, T. peruviana, and $C$. procera combined with fungicide, increased peroxidase activity $24 \mathrm{~h}$ after inoculation by 266,137 , and $172 \%$, respectively, compared with the inoculated control. Peroxidase activity remained high in the half-dose formulation of J. mimosifolia-treated plants until $96 \mathrm{~h}$ after inoculation. Inoculated plants pretreated with the combined formulation of $J$. mimosifolia and fungicide had the highest levels of peroxidase activity.

Chitinase activity. Inoculation induced higher chitinase activity in treated plants compared with untreated plants (Fig. 6B). Maximum chitinase activity was observed $24 \mathrm{~h}$ after inoculation, followed by a decline in activity from 48 to $96 \mathrm{~h}$. The fungicide treatment; leaf extracts of J. mimosifolia, T. peruviana, or $C$. procera; or SA increased chitinase activity by $52,48,50,50$, and $65 \%$, respectively. The half-dose formulations of the aqueous leaf extracts of J. mimosifolia, T. peruviana, or C. procera combined with fungicide significantly increased chitinase activity $24 \mathrm{~h}$ after pathogen inoculation by 128,68 , and $76 \%$, respectively.

$\beta-1,3-G l u c a n a s e$ activity. $\beta$-1,3-Glucanase activity was higher in inoculated plants treated with extracts than in untreated plants (Fig. 6C). Maximum $\beta$-1,3-glucanase activity was observed 24 and $48 \mathrm{~h}$ after inoculation, followed by a decline from 72 to $96 \mathrm{~h}$. Fungicide treatment; leaf extracts of J. mimosifolia, T. peruviana, or $C$. procera; or SA increased $\beta$-1,3-glucanase activity by 123 , $100,89,77$, and 74\%, respectively. Among the half-dose formulations, the aqueous leaf extracts of J. mimosifolia, T. peruviana, and $C$. procera combined with fungicide increased $\beta$-1,3-glucanase activity $24 \mathrm{~h}$ after inoculation by 138, 102, and $155 \%$, respectively. Activity remained high in the half-dose J. mimosifolia extract combined with fungicide, then declined at $72 \mathrm{~h}$ after pathogen inoculation. J. mimosifolia extract combined with fungi- cide was more effective in increasing $\beta$-1,3-glucanase activity than the other treatments.

PAL activity. PAL activity $24 \mathrm{~h}$ after inoculation was higher in plants pretreated with aqueous leaf extracts than in untreated plants (Fig. 6D). Single applications of fungicide; extracts of J. mimosifolia, T. peruviana, or C. procera; or SA alone increased PAL activity by $34,26,15,16$, and $98 \%$, respectively. The halfdose formulations of $J$. mimosifolia, $T$. peruviana, or $C$. procera combined with fungicide significantly increased PAL activity $24 \mathrm{~h}$ after inoculation by 140,64 , and $79 \%$, respectively. Activity remained high in the half-dose formulation of J. mimosifolia combined with fungicide-treated plants before declining $72 \mathrm{~h}$ after inoculation.

\section{DISCUSSION}

Here, we examined the ability of aqueous leaf extracts of $J$. mimosifolia, T. peruviana, and C. procera to protect wheat against the leaf rust fungus, $P$. triticina. We showed first that the plant formulations inhibited urediniospore germination and germ tube development of $P$. triticina in vitro. Inhibition of urediniospore germination was most effective with leaf extracts of J. mimosifolia. Subramani et al. (62) demonstrated in vitro inhibitory effects of leaf extracts of Adhatoda vasica, Azadirachta indica, and Lantana camara against the germination of coffee leaf rust (Hemileai vastatrix) urediniospores (62). Cawood et al. (13) showed that extracts of Agapanthus africanus and Tulbaghia violacea had significant inhibitory effects on the germination of $P$. triticina spores, and that foliar application of $T$. violacea extracts increased peroxidase, chitinase, and $\beta$-1,3-glucanase enzyme activities in response to $P$. triticina infection in wheat (13).

We then conducted gene expression analysis at the mRNA level of the treated wheat plants. This revealed that all foliar treatments upregulated expression of defense-related genes (Chil, Chi4, Glu1, POD, PR-1.1, PR-1.2, PR-1a, PR-4, and PR-5) $24 \mathrm{~h}$ after inoculation, and that the expression of each of these genes significantly correlated with the observed reduction in disease incidence. Half-dose formulations of plant extracts combined with fungicide also upregulated the expression of Chil, Chi4, PR-4, PR-5, PR-1.1, $P R-1.2$, Glul, and PR-la. Most PR-proteins, including chitinases and $\beta$-1,3-glucanases, have antimicrobial activity, including the capacity to degrade fungal cell walls (31). PR-4 and PR-9 have peroxidase and ribonuclease activity, respectively (12). The induction of specific PR proteins such as $P R-1 a, P R-2$, and $P R-5$ correlates with the onset of SAR (59), which can also be induced by the exogenous application of SA in wheat (43).

The third part of our study showed that pretreatment with plant extracts increased levels of apoplastic PR proteins above the

TABLE 4. Identification of proteins in bands excised from one-dimensional electrophoresis gels run with intercellular washing fluid from wheat leaves sprayed with various formulations prior to pathogen inoculation (Fig. 4) ${ }^{\mathrm{a}}$

\begin{tabular}{|c|c|c|c|c|c|}
\hline Band number & GI number & Protein identification & Species & Mass (kDa) & MASCOT Score \\
\hline 1 & 182382494 & Subtilisin protease & Triticum aestivum & 59 & 28 \\
\hline 2 & 90652740 & $\beta$-Glucosidase & T. aestivum & 64 & 147 \\
\hline 3 & 90990912 & $\beta$-Glucosidase & T. aestivum & 64 & 222 \\
\hline 5 & 205830697 & Unknown protein 18 & & 14 & 203 \\
\hline 6 & 283806355 & Aminotransferase & T. aestivum & 55 & 151 \\
\hline 7 & 57635157 & Peroxidase 6 & T. mопососсит & 35 & 383 \\
\hline 8 & 57635153 & Peroxidase 4 & T. mопососсит & 33 & 290 \\
\hline 11 & 416029 & Endochitinase & T. aestivum & 34 & 61 \\
\hline 12 & 72256523 & 4-Hydroxyphenylpyruvate dioxygenase & T. aestivum & 47 & 52 \\
\hline 13 & 357122848 & Peroxidase 54-like & Brachypodium distachyon & 36 & 87 \\
\hline 14 & 90990912 & $\beta$-Glucosidase & T. aestivum & 35 & 1,086 \\
\hline 15 & 68250406 & $\beta$-1,3-Glucanase & T. aestivum & 35 & 1,280 \\
\hline
\end{tabular}

a The GI number, protein name, source organism, mass in kilodaltons (kDa) from database, and MASCOT score of the identified peptides via electrospray ionization tandem mass spectrometry analysis are shown. 
increases caused by inoculation alone (51). PR proteins have a crucial role in plant defense (64), and those such as $\beta$-1,3-glucanases, peroxidase, chitinase, and subtilisin-like proteases have been reported in the apoplast of pathogen-inoculated wheat $(2,50)$. Extracts of J. mimosifolia alone, as well as in combination with fungicide, induced the highest levels of PR-proteins after inoculation, including subtilisin protease, $\beta$-glucosidase, $(1,3 ; 1,4) \beta$ glucanase, endochitinases, peroxidases, and PAL. $C$. procera extract with a half-dose of fungicide gave the maximum level of increase in $\beta$-1,3-glucanase activity compared with untreated, inoculated plants. The formulations of $J$. mimosifolia and C. procera leaf extracts acted synergistically with fungicide to augment protease, peroxidase, chitinase, $\beta$-1,3-glucanase, and PAL activities.

The involvement of $\beta$-1,3-glucanase in the defense response of wheat to leaf rust has been shown by following the induction of $\beta$-1,3-glucanase activity within $48 \mathrm{~h}$ after infection. Anguelova et al. (6) found that high levels of $\beta$-1,3-glucanase activity were induced during advanced stages of colonization (6), while Anguelova-Merhar et al. (7) revealed the synergistic interaction of chitinase and $\beta$-1,3-glucanase in hydrolyzing fungal cell walls, providing defense in a leaf rust-resistant cultivar against inoculated pathogens (7).

ROS are considered to play a major role in the signaling and expression of defense, including lipid peroxidation, the hypersensitive response, and production of lignin, polyphenols, and phytoalexins (40). ROS produced by the host plant act directly on the pathogen (4) and also induce systemic resistance in the host plant (49), which includes increased levels of the PR-proteins peroxidase, $\beta$-1,3-glucanase, and chitinase (68).

Peroxidases and PAL are also involved in defense responses to pathogen attack $(29,32)$. Peroxidases reinforce plant cell walls by catalyzing lignification $(36,47)$. PAL is the first committed enzyme in the phenylpropanoid and flavonoid pathways; is involved in the biosynthesis of phytoalexins, lignins, and SA associated with disease resistance (41); and is also involved in synthesis of the defense-related compounds lignin and phenolics. Overall, the enhanced level of apoplastic peroxidase, chitinase, $\beta$-1,3-glucanase, and PAL activities in rust-infected wheat leaves may play an important role in strengthening the cell walls of the host plant to resist pathogen infection.

Crude extracts of certain plant species are known to contain antifungal compounds, such as the four flavonoids and a steroidal saponin identified in extracts of A. africanas (63). However, although specific (unidentified) anti-fungal compounds present in the extracts used in our study might be responsible for the inhibition of urediniospore germination in P. triticina, their presence is unlikely to explain the induction of plant defense responses prior to pathogen inoculation. The mechanisms by which aqueous plant extracts sprayed onto wheat leaves can induce the expression of defense or PR proteins and enhance plant resistance to leaf rust remain unknown (see above). Specific plant extracts have been reported to induce systemic resistance in plants, as well as disease reduction and increased plant growth in agricultural crops $(45,53)$. The mechanism of disease suppression by plant products suggested that their active compounds either might act on pathogens directly or induce systemic resistance in host plants, resulting in reduction of disease development (49). The inducing compounds might be identified through fractionating the aqueous leaf extracts (by molecular size, hydrophobicity, and other parameters) and testing each fraction for its protective affect against leaf rust. However, it is also likely that components of the highly complex mixture of compounds in the leaf extracts act synergistically to induce defense responses.

We examined the gene expression data (Fig. 2) to determine whether treatments tended to be additive, or whether some treatments were synergistic or antagonistic (Supplementary Table 2). One of the most important potential interactions here was the interaction between fungicide (Amx) and the various leaf extracts. For this, we performed the following calculation for each individual gene and extract (the example here is for the J. mimosifolia

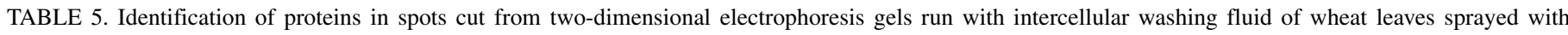
various formulations prior to pathogen inoculation (Fig. 5) ${ }^{\mathrm{a}}$

\begin{tabular}{|c|c|c|c|c|c|}
\hline Spot number & GI number & Protein description & Species & Mass (kDa) & MASCOT score \\
\hline 1 & 300681540 & Unnamed protein product & Triticum aestivum & 18 & 32 \\
\hline 2 & 172046673 & Unknown protein 1 & $\ldots$ & 10 & 49 \\
\hline 3 & 205830697 & Unknown protein 18 & $\ldots$ & 14 & 109 \\
\hline 4 & 147841400 & Hypothetical protein VITISV_019908 & Vitis vinifera & 66 & 47 \\
\hline 5 & 357114586 & Subtilisin-like protease-like & Brachypodium distachyon & 79 & 287 \\
\hline 6 & 148299083 & Subtilisin-like protease & Nicotiana tabacum & 81 & 82 \\
\hline 7 & 311764 & $(1,3 ; 1,4)-\beta$-Glucanase & T. aestivum & 35 & 433 \\
\hline 8 & 305691103 & Leaf rust resistance protein $\mathrm{Lr} 10$ & T. dicoccoides & $\ldots$ & 20 \\
\hline 9 & 37788312 & Cyclophilin-like protein & T. aestivum & 26 & 540 \\
\hline 10 & 45862004 & Putative vacuolar defense protein & T. aestivum & 18 & 50 \\
\hline 11 & 194707740 & Unknown protein & Zea mays & 24 & 159 \\
\hline 12 & 1572627 & $\mathrm{Cu} / \mathrm{Zn}$ superoxide dismutase & T. aestivum & 20 & 494 \\
\hline 13 & 205830697 & Unknown protein 18 & $\ldots$ & 14 & 153 \\
\hline \multirow[t]{2}{*}{14} & 300681553 & tRNA (guanine-N(1)-)-methyltransferase, putative, & & & \\
\hline & & expressed TPA: hypothetical protein & T. aestivum & 51 & 15 \\
\hline 15 & 414881288 & ZEAMMB73_571858 & Z. mays & 46 & 58 \\
\hline 16 & 357122848 & Peroxidase 54-like & B. distachyon & 36 & 127 \\
\hline 17 & 311764 & $(1,3 ; 1,4)-\beta$-Glucanase & T. aestivum & 35 & 573 \\
\hline 18 & 48093224 & Chitinase & T. dactyloides & 29 & 94 \\
\hline 19 & 311764 & $(1,3 ; 1,4)-\beta$-Glucanase & T. aestivum & 35 & 89 \\
\hline 20 & 189016844 & Class III peroxidase & T. aestivum & 33 & 22 \\
\hline 21 & 205830697 & Unknown protein 18 & $\ldots$ & 14 & \\
\hline 22 & 147797596 & Hypothetical protein VITISV_024891 & $V$. vinifera & 56 & 120 \\
\hline 23 & 326493636 & Predicted protein & Hordeum vulgare & 48 & 47 \\
\hline 24 & 147800078 & Hypothetical protein VITISV_032320 & $V$. vinifera & 40 & 87 \\
\hline 25 & 357122848 & Peroxidase 54-like & B. distachyon & 36 & 154 \\
\hline 26 & 226497656 & Uncharacterized protein LOC100272900 & Z. mays & 36 & 117 \\
\hline 27 & 311764 & $(1,3 ; 1,4)-\beta-$-Glucanase & T. aestivum & 35 & 83 \\
\hline 28 & 115345282 & Peroxidase & Populus alba & 33 & 496 \\
\hline 29 & 359950740 & R1R2R3-MYB protein & T. aestivum & 95 & 81 \\
\hline
\end{tabular}

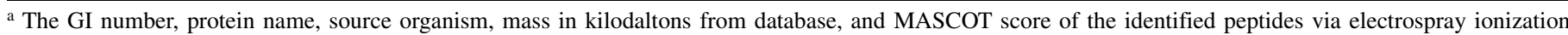
tandem mass spectrometry analysis are shown. 
treatment). [1] Expression due to $\mathrm{Amx}=\mathrm{Amx}+P$. triticina $(\mathrm{Pt})-$ Pt. [2] Expression due to J. mimosifolia $(\mathrm{Jm})=\mathrm{Jm}+\mathrm{Pt}-\mathrm{Pt}$. [3] Expression due to a combination of Amx and $\mathrm{Jm}=(\mathrm{Jm}+\mathrm{Amx}+$ $\mathrm{Pt})-\mathrm{Pt}$. If [3] $-([2]+[1]) \approx 0$, there is no interaction between Amx and J. mimosifolia (effects are additive); if $>>0$, Amx and $J$. mimosifolia are synergistic; and if $<<0$, Amx and J. mimosifolia are antagonistic. We then expressed the value obtained as a percentage of [3] to allow comparisons across genes. Amx and J. mimosifolia were found to be additive or somewhat synergistic for all genes except PR1.1, for which Amx and J. mimosifolia were antagonistic. Amx and T. peruviana (Tp) were additive or somewhat synergistic or antagonistic (depending on the gene), except for Chi-1, for which Amx and Tp were antagonistic. Amx and $C$. procera $(\mathrm{Cp})$ were additive or somewhat synergistic or antagonistic for all nine genes examined. Overall, there was no clear evidence for synergistic or antagonistic effects of the combination of fungicide and leaf extract treatments on defenserelated gene expression.

The level of gene expression for plants treated with Amx $+P$. triticina was considerably higher than for plants treated with $P$. triticina alone. Indeed, whereas the average increase in expression (across all nine genes tested) attributable to the effect of $P$. triticina (the pathogen) on $\mathrm{C}$ (the uninoculated control) was 1.8-fold, the effect of Amx on P. triticina was 5.0-fold (Fig. 2). The effects of Amx on $\mathrm{Jm}+\mathrm{Pt}$, $\mathrm{Tp}+\mathrm{Pt}$, and $\mathrm{Cp}+\mathrm{Pt}$ (2.6-, 3.2-, and 3.7-fold, respectively) and the effects of $\mathrm{SA}$ on $\mathrm{Jm}+\mathrm{Pt}, \mathrm{Tp}+\mathrm{Pt}$, and $\mathrm{Cp}+\mathrm{Pt}$
(1.0-, 1.5-, and 1.7-fold, respectively) were all less than the effect of Amx on P. triticina. Thus, it is important to consider the mode of action of Amx and whether anything is known about its apparent ability to induce defense responses. The components of Amistar Xtra are azoxystrobin and cyproconazole. Azoxystrobin is an analog of strobilurin A, a compound derived from particular species of European mushrooms, and has been shown to induce plant defense responses (5). These workers found that spray treatment of 30-day-old cucumber plants growing in pots with 0.25 , 0.5 , and $1.0 \mathrm{ml} \mathrm{liter}{ }^{-1}$ resulted in dose-dependent increases over 3 days in POD, polyphenol oxidase, PAL, $\beta$-1,3-glucanase, and chitinase activity compared with untreated controls, before the activities reached a plateau.

According to Jørgensen et al. (27), azoxystrobin is classified as very toxic to aquatic organisms and defined as moderately to highly persistent in soil, which supports the importance of our study in finding alternative management practices to reduce its use (27). We conclude from our results that foliar treatment of a susceptible wheat cultivar with leaf extracts of $J$. mimosifolia, $T$. peruviana, and $C$. procera in combined formulations with fungicide were able to induce resistance to subsequent inoculation with $P$. triticina, apparently through the accumulation of defenserelated proteins in the apoplast. Further testing of leaf extracts from other plant species on wheat or other host plants and against other pathogens may expand the potential of this crop protection strategy.
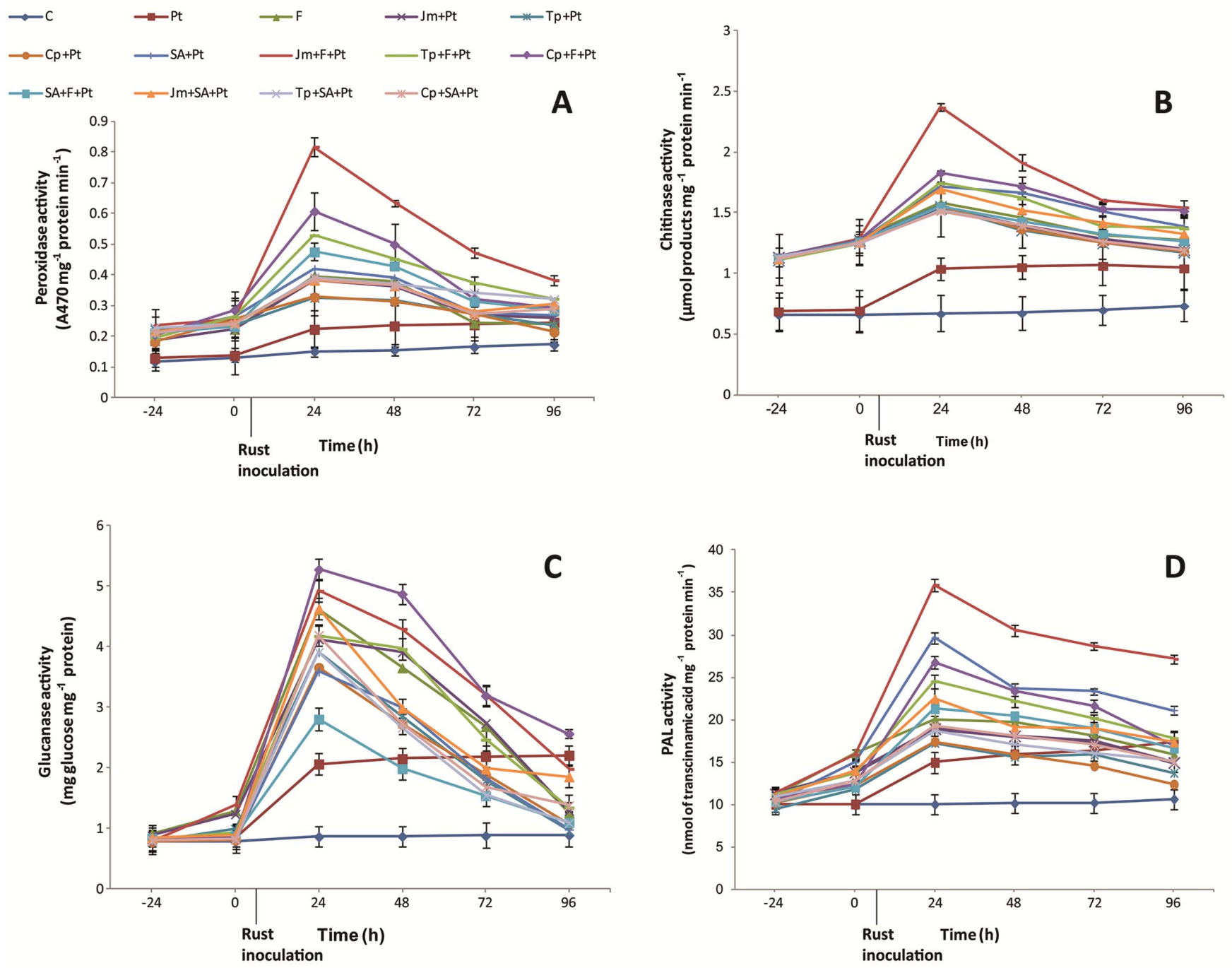

Fig. 6. Effect of plant extract formulations on defense-related enzyme activities. A, peroxidase activity. B, Chitinase activity. C, $\beta-1,3-$ Glucanase activity. D, Phenylalanine ammonia lyase (PAL) activity. Points represent means with standard errors $(n=3)$. Labeling is explained in Table 1 . 


\section{ACKNOWLEDGMENTS}

R. Naz acknowledges the award of financial support from an International Research Support Initiative Program by the Higher Education Commission of Pakistan. We thank R. Park (Plant Breeding Institute, University of Sydney) and B. Crossett (Sydney University Proteome Research Unit) for assistance with pathology and proteomics aspects of this work, respectively.

\section{LITERATURE CITED}

1. Abeles, F. B., and Forrence, L. E. 1979. Temporal and hormonal control of $\beta-1,3$-glucanase in Phaseolus vulgaris L. Plant Physiol. 45:395-400.

2. Aleandri, M. P., Magro, P., and Chilosi, G. 2008. Influence of environmental $\mathrm{pH}$ modulation on efficiency of apoplastic PR proteins during Fusarium culmorum-wheat seedling interaction. Plant Pathol. 57:10171025 .

3. Al-Samarrai, G., Singh, H., and Syarhabil, M. 2012. Evaluating ecofriendly botanicals (natural plant extracts) as alternatives to synthetic fungicides. Ann. Agric. Environ. Med. 19:673-676.

4. Amadioha, A. C. 2000. Controlling rice blast in vitro and in vivo with extracts of Azadirachta indica. Crop Prot. 19:287-290.

5. Anand, T., Chandrasekaren, A., Kuttalam, S., Raguchander, T., and Samiyappan, R. 2009. Management of cucumber (Cucumis sativus L.) mildews through azoxystrobin-tolerant Pseudomonas fluorescens. J. Agric. Sci. Technol. 11:211-226.

6. Anguelova, V. S., van der Westhuizen, A. J., and Pretorius, Z. A. 1999. Intercellular proteins and $\beta$-1,3-glucanase activities associated with leaf rust resistance in wheat. Physiol. Plant. 106:393-401.

7. Anguelova-Merhar, V. S., van der Westhuizen, A. J., and Pretorius, Z. A. 2001. $\beta-1,3$-Glucanase and chitinase activities and the resistance response of wheat to leaf rust. J. Phytopathol. 149:381-384.

8. Assis, J. S., Maldonado, R., Munoz, Escribano, M. I., and Merodio, C. 2001. Effect of high carbon dioxide concentration on PAL activity and phenolic contents in ripening cherimoya fruit. Postharvest Biol. Technol. 23:33-39.

9. Bi, Y., Tian, S. P., Guo, Y. R., Ge, Y. H., and Qin, G. Z. 2006. Sodium silicate reduces postharvest decay on Hami melons: induced resistance and fungistatic effects. Plant Dis. 90:279-283.

10. Bowles, D. J. 1990. Defence-related proteins in higher plants. Annu. Rev. Biochem. 59:873-907.

11. Bradford, M. M. 1976. A rapid and sensitive method for the quantitation of microgram quantities of protein utilizing the principle of protein-dye binding. Anal. Biochem. 72:248-254.

12. Caporale, C., Di Berardino, I., Leonardi, L., Bertini, L., Cascone, A., Buonocore, V., and Caruso, C. 2004. Wheat pathogenesis-related proteins of class 4 have ribonuclease activity. FEBS Lett. 575:71-76.

13. Cawood, M. E., Pretorius, J. C., van der Westhuizen, A. J., and Pretorius, Z. A. 2010. Disease development and PR-protein activity in wheat (Triticum aestivum) seedlings treated with plant extracts prior to leaf rust (Puccinia triticina) infection. Crop Prot. 29:1311-1319.

14. Conrath, U., Thulke, O., Katz, V., Schwindling, S., and Kohler, A. 2001. Priming as a mechanism in induced systemic resistance of plants. Eur. J. Plant Pathol. 107:113-119.

15. Dani, V., Simon, W. J., Duranti, M., and Croy, R. R. D. 2005. Changes in the tobacco leaf apoplast proteome in response to salt stress. Proteomics 5:737-745

16. Delaney, T. P. 2004. Salicylic acid. Pages 635-653 in: Plant Hormones. P. J. Davies, ed. Kluwer Academic Press, Dordrecht, The Netherlands.

17. Dietz, K. J. 2000. The extracellular matrix of the plant cell: Location of signal perception, transduction and response. Pages 215-237 in: Progress in Botany. K. Esser, U. Lüttge, J. Kadereit, and W. Beyschlag, eds. Springer, Berlin Heidelberg New York.

18. Durner, J., Shah, J., and Klessig, D. F. 1997. Salicylic acid and disease resistance in plants. Trends Plant Sci. 2:266-274.

19. Gata, G. L., Nogueira, J. M. F., and Bruno de Sousa, O. M. R. 2003. Photoactive extracts from Thevetia peruviana with antifungal properties against Cladosporium cucumerinium. J. Photochem. Photobiol. 70:51-54.

20. Gomez, K. A., and Gomez, A. A. 1984. Statistical Procedures for Agricultural Research. John Wiley and Sons, New York.

21. Hammerschmidt, R. 1999. Induced disease resistance: how do induced plants stop pathogens? Physiol. Mol. Plant Pathol. 55:77-84.

22. Hammond-Kosack, K. E. 1992. Preparation and analysis of intercellular fluid. Pages 15-30 in: Molecular Plant Pathology: A Practical Approach II. S. J. Gurr, M. J. McPherson, and D. J. Bowles, eds. IRL Press/Oxford University Press, Oxford.

23. Heath, M. C. 1998. Apoptosis, programmed cell death and the hypersensitive cell death. Eur. J. Plant Pathol. 104:117-124.

24. Holden, D. W., and Rohringer, R. 1985. Proteins in intercellular washing fluid from non-inoculated and rust-affected leaves of wheat and barley. Plant Physiol. 78:715-723.

25. Husted, S., and Schjoerring, J. K. 1995. Apoplastic pH and ammonium concentration in leaves of Brassica napus L. Plant Physiol. 109:14531460.

26. Iftikhar, T., Niaz, M., Hussain, Y., Abbas, S. Q., Ashraf, I., and Zia, M. A. 2010. Improvement of selected strains through gamma irradiation for enhanced lipolytic potential. Pak. J. Bot. 42:2257-2267.

27. Jørgensen, L. F., Kjær, J., Olsen, P., and Rosenbom, A. B. 2012. Leaching of azoxystrobin and its degradation product R234886 from Danish agricultural field sites. Chemosphere 88:554-562.

28. Kemp, G., Botha, A. M., Kloppers, F. J., and Pretorius, Z. A. 1999. Disease development and $\beta$-1,3-glucanase expression following leaf rust infection in resistant and susceptible near-isogenic wheat seedlings. Physiol. Mol. Plant Pathol. 55:45-52.

29. Khairullin, R. M., Yusupova, Z. R., and Troshina, N. B. 2000. Protective responses of wheat treated with fungal pathogens: 2 . Activation of anionic peroxidase isoforms in wheat seedlings induced by inoculation with Tilletia caries spores. Russ. J. Plant Physiol. 47:114-119.

30. Kolmer, J. A. 2005. Tracking wheat rust on a continental scale. Curr Opin. Plant Biol. 8:441-449.

31. Lay, F. T., and Anderson, M. A. 2005. Defensins-components of the innate immune system in plants. Curr. Protein Peptide Sci. 6:85-101.

32. Liu, M. X., and Kolattukudy, P. E. 1997. Expression of an anionic peroxidase and oxidative burst in tomato cells induced by the elicitor from Verticillium albo-atrum. Acta Phytophysiol. Sin. 23:220-226.

33. Lopes, M. A., Gomes, D. S., Koblitz, M. G. B., Pirovani, C. P. Cascardo, J. C. M., Góes-Neto, A., and Micheli, F. 2008. Use of response surface methodology to examine chitinase regulation in the basidiomycete Moniliophthora perniciosa. Mycol. Res. 112:399-406.

34. Lu, Z. X., Gaudet, D., Puchalski, B., Despins, T., Rick, M., and Laroche, A. 2006. Inducers of resistance reduce common bunt infection in wheat seedlings while differentially regulating defence-gene expression. Physiol. Mol. Plant Pathol. 67:138-148.

35. Ly, L., and Wasinger, V. C. 2011. Protein and peptide fractionation, enrichment and depletion: tools for the complex proteome. Proteomics 11:513-534.

36. Maksimov, I. V., Cherepanova, E. A., Kuzmina, O. I., Yarullina, L. G., and Achunov, A. V. 2010. Molecular peculiarities of the chitin-binding peroxidases of plants. Russ. J. Bioorg. Chem. 13:293-300.

37. Malamy, J., and Klessig, D. F. 1992. Salicylic acid and plant disease resistance. Plant J. 2:643-654.

38. Manoharachary, C., and Gourinath, A. 1988. Effects of plant extracts on four pathogenic fungi. In: 5th Int. Congr. Plant Pathol. Kyoto, Japan.

39. Marchetti, O., Moreillon, P., Glauser, M. P., Bille, J., and Sanglard, D. 2000. Potent synergism of the combination of fluconazole and cyclosporine in Candida albicans. Antimicrobiol. Agents Chemother. 44:23732381.

40. Martínez, J. A. 2012. Natural Fungicides Obtained from Plants, Fungicides for Plant and Animal Diseases. D. Dhanasekaran, ed. InTech, Rijeka, Croatia.

41. Mauch-Mani, B., and Slusarenko, A. J. 1996. Production of salicylic acid precursors is a major function of phenylalanine ammonia lyase in the resistance of Arabidopsis to Peronospora parasitica. Plant Cell 8:203212.

42. McIntosh, R. A., Wellings, C. R., and Park, R. F. 1995. Wheat Rusts: An Atlas of Resistance Genes. CSIRO Publications, Victoria, Australia.

43. Molina, A., Gölach, J., Volrath, S., and Ryals, J. 1999. Wheat encoding two types of PR-1 proteins are pathogen inducible, but do not respond to activators of systemic acquired resistance. Mol. Plant-Microbe Interact. 12:53-58.

44. Muthukrishnan, S., Liang, G. H., Trick, H. N., and Gill, B. S. 2001. Pathogenesis-related proteins and their genes in cereals. Plant Cell 64:93-114.

45. Nandakumar, R., Babu, S., Viswanathan, R., Raguchander, T., and Samiyappan, R. 2001. Induction of systemic resistance in rice against sheath blight disease by Pseudomonas fluorescens. Soil Biol. Biochem. 33:603-612.

46. Nashwa, S. M. A., and Abo-Elyousr, K. A. M. 2012. Evaluation of various plant extracts against the early blight disease of tomato plants under greenhouse and field conditions. Plant Prot. Sci. 2:74-79.

47. Passardi, F., Penel, C., and Dunand, C. 2004. Performing the paradoxical: how plant peroxidases modify the cell wall. Trends Plant Sci. 9:534-540.

48. Pathak, N., and Zaidi, R. K. 2013. Comparative study of seed dressing fungicides and Calotropis procera latex for the control of seed-borne mycoflora of wheat. Ann. Biol. Res. 4:1-6.

49. Paul, P. K., and Sharma, P. D. 2002. Azadirachta indica leaf extract induces resistance in barley against leaf stripe disease. Physiol. Mol. Plant Pathol. 61:3-13.

50. Pearce, G., Yamaguchi, Y., Barona, G., and Ryan, C. A. 2010. A subtilisinlike protein from soybean contains an embedded, cryptic signal that 
activates defense-related genes. Proc. Natl. Acad. Sci. USA 107:1492114925.

51. Pós, V. 2010. Leaf rust and cadmium-induced changes in the protein pattern of the apoplast of wheat and barley. Ph.D. thesis, Corvinus University of Budapest.

52. Rai, M., and Carpinella, M. 2006. Naturally Occurring Bioactive Compounds. Elsevier, Amsterdam.

53. Ramamoorthy, V., Raguchander, T., and Samiyappan, R. 2002. Enhancing resistance of tomato and hot pepper to Pythium diseases by seed treatment with fluorescent Pseudomonads. Eur. J. Plant Pathol. 108:429441.

54. Reddy, B. U. 2010. Antimicrobial activity of Thevetia peruviana (Pers.) K. Schum. and Nerium indicum Linn. Internet J. Pharmacol. 8:2.

55. Röhrig, H., Schmidt, J., Colby, T., Bräutigam, A., Hufnagel, P., and Bartels, D. 2006. Desiccation of the resurrection plant Craterostigma plantagineum induces dynamic changes in protein phosphorylation. Plant Cell Environ. 29:1606-1617.

56. Rohringer, R., Ebrahim-Nesbat, F., and Wolf, G. 1983. Proteins in intercellular washing fluids from leaves of barley (Hordeum vulgare L.). J. Exp. Bot. 34:1589-1605.

57. Rojas, J. J., Ochoa, V. J., Ocampo, S. A., and Munoz, J. F. 2006. Screening for antimicrobial activity of ten medicinal plants used in Colombian folkloric medicine: a possible alternative in the treatment of non-nosocomial infections. BMC Complement. Altern. Med. 6:2.

58. Roopa, S. V., and Wadje, S. S. 2012. In-vivo testing of plant extracts against seed borne pathogens. Int. Res. J. Biol. Sci. 1:1-4.

59. Ryals, J. A., Neuenschwander, U. H., Willits, M. G., Molina, A., Steiner, H. Y., and Hunt, M. D. 1996. Systemic acquired resistance. Plant Cell 8:1809-1819.

60. Sattelmacher, B., Mühling, K. H., and Pennewib, K. 1998. The apoplastits significance for the nutrition of higher plants. J. Plant Nutr. Soil Sci.
161:485-498.

61. Stangarlin, J. R., and Pascholati, S. F. 2000. Activities of ribulose-1,5bisphosphate carboxylase-oxygenase (Rubisco), chlorophyllase, $\beta-1,3$ glucanase and chitinase and chlorophyll content in bean cultivars (Phaseolus vulgaris) infected with Uromyces appendiculatus. Summa Phytopathol. 26:34-42.

62. Subramani, D., Rajanaika, Chinnaswamy, K. K. K., Singh, S., Kumar, V. K. P., Bhat, S. S., and Jayarama. 2012. Comparative efficacy of plant products on the spore germination and disease incidence of coffee leaf rust pathogen. Acta Biol. Indica 1:69-75.

63. Tegegne, G., Pretorius, J. C., and Swart, W. J. 2008. Antifungal properties of Agapanthus africanus L. extracts against plant pathogens. Crop Prot. 27:1052-1060.

64. van Loon L. C., Rep, M., and Pieterse, C. M. J. 2006. Significance of inducible defence-related proteins in infected plants. Annu. Rev. Phytopathol. 44:135-62.

65. Veronese, P., Ruiz, M. T., Coca, M. A., Hernandez-Lopez, A., Lee, H., and Ibeas, J. I. 2003. In plant defense against pathogens. Both plant sentinels and food soldiers need to know the enemy. Plant Physiol. 131:1580-1590.

66. Walters, D. R., Newton, A. C., and Lyon, G. D. 2005. Induced resistance: helping plants to help themselves. Biologist 52:28-33.

67. Wang, W., Scali, M., Vignani, R., Spadafora, A., Sensi, E., Mazzuca, S., and Cresti, M. 2003. Protein extraction for two-dimensional electrophoresis from olive leaf, a plant tissue containing high levels of interfering compounds. Electrophoresis 24:2369-2375.

68. Xue, L., Charest, P. M., and Jabaji-Hare, S. H. 1998. Systemic induction of peroxidases, $\beta$-1,3-glucanases, chitinases and resistance in bean plants by binucleate Rhizoctonia species. Phytopathology 88:359-365.

69. Yang, V. W., and Clausen, C. A. 2007. Antifungal effect of essential oils on southern yellow pine. Int. Biodeter. Biodegr. 59:302-306. 